\title{
Exploring Saudi EFL Learners’ Agency Toward the Use of WhatsApp for English Learning at Qassim University
}

\author{
Fahd H. Alqasham \\ College of Humanities and Social Studies, Massey University \\ PO Box 4410, Palmerston North, New Zealand \\ E-mail: f.alqasham@gmail.com
}

Received: Nov. 4, 2018 Accepted: November 14, 2018 Published: November 29, 2018

doi:10.5296/ijl.v10i6.13857

URL: https://doi.org/10.5296/ijl.v10i6.13857

\begin{abstract}
This study investigates a Saudi tertiary EFL (English as a foreign language) students' experiences and use trajectory of WhatsApp for their out of class English learning in a longitudinal study for a 12-week semester. The study utilized agency theory (van Lier, 2004, 2008,2010 ) as the analytical tool to acquire a deeper understanding of how the students' use of WhatsApp could introduce innovative ways that could assist them to practice and collaborate in English learning outside the classroom. A mixed methods approach was adopted for data collection and included six instruments consisting of initial and post-project interviews, focus group participation, a post-project questionnaire, observations, and research log to gather data from the students' use of WhatsApp. The participants were 25 male students who are studying in the first and second levels of the Preparatory Year Program (PYP) at the main campus of Qassim University. The study results showed that WhatsApp's implementation demonstrated its sustainability outside the classroom for English learning as evident by the students' continued use of WhatsApp even after the study ended by the 12th week; in fact, they continued to use it until the end of the semester (week 17). The affordances of WhatsApp allowed the students to develop autonomy, to practice what they were learning, to collaborate with each other, and to shift from being passive learners to active ones, not only in English studies but in other subjects as well. Finally, this study concludes by demonstrating the significance of interpreting the dynamic and complex nature of the innovation's implementation process through the lens of van Lier's agency theory from an ecological perspective. It also identifies the limitations of the study and recommends ways in which researchers could investigate the advantages of social networking in the language classroom.
\end{abstract}


Keywords: Agency, Agency in language learning, EFL learning, English learning, Social media, Social networking, WhatsApp, Language learning 


\section{Introduction}

The great impact of the Internet and Web 2.0 on language learning and teaching over the past 20 years is evidenced by the enormous and unique body of research in different fields, including second language acquisition (SLA), language pedagogy and assessment, computer-mediated communication, and discourse analysis. Precisely, the combination of the Internet and computer-assisted language learning (CALL) received major attention in the past years due to its potential in enhancing SLA (e.g., Chun, 1994; Kern, 1995). The social aspects associated with the use of the Internet, in particular through Web 2.0 or social networking applications including Twitter, Facebook, blogs, wikis, and various related media technologies, services, and platforms, along with mobile accessibility, began to support innovative examples of social interaction that reformed the use of technology in SLA (Lankshear \& Knobel, 2006; Warschauer \& Grimes, 2007).

This major trend is in line with the Saudi Ministry of Education's (MOE) efforts which focus on developing innovation in education (Alresheed, Leask, \& Raiker, 2015; Saqlain, Al-Qarni, \& Ghadi, 2013). The Saudi MOE's attention to the implementation of technology in education can be seen with its various projects to digitalize learning over the past years. For instance, in 2006 The Saudi MOE proposed to a national plan to implement technologies in education, so as to develop its educational outcomes (Ministry of Communications and Information Technology (MOCIT), 2009). The following year, 2007, the MOE introduced another project called Tatweer program (www.tatweer.edu.sa) in which the main purpose of it was to reform and enhance education in Saudi universities and schools with a particular emphasis on technology development and implementation over a six-year period (Albugami \& Ahmed, 2015). More recently, in March 2017, the MOE funded a technological shift in Saudi education with approximately $\$ 426$ million, through signing a contract with a company specializing in digital technology, in an effort to supply 1500 universities and schools with smart tablets for the teachers and students. The Saudi's ongoing efforts to digitalize learning did not stop at this point; they continued by launching a website www.ebook.sa with a goal to replace textbooks with eBooks. The Saudi ministry's interests in innovative technology as a way to develop education indicates its importance and value, as well as its potential to influence the Saudi youth since they are familiar with the use of technology.

As for the English language, the Saudi MOE treats English as an important and essential subject in education (Asiri, 2014). English was introduced in 1925 in the school curriculum beginning from middle school, and recently was moved to the elementary stage, specifically from the fourth grade (usually 10 years old) as a compulsory subject and up to tertiary education (Mitchell \& Alfuraih, 2017). The MOE's purpose in introducing English from the primary stage is mainly to equip Saudis with an international language that can aid the kingdom with its economy and other essential needs, and allow them to acquire the macro skills of English (writing, reading, speaking and listening), so as to be able to communicate with English speakers (Al-Ahaydib, 1986; Aldosari, 1992).

Although Saudi English learners have been studying English for a long period of time, particularly since grade four, and despite the Saudi MOE's efforts to develop English 
learning in schools and universities, the language level of Saudis is still insufficient to carry out even basic interactions, exhibiting relatively low achievements (Al-Johani, 2009; Al-Seghayer, 2014; Alhawsawi, 2013; Alrabai, 2016; Khan, 2011; Rajab, 2013). This argument is further proven with the results of a recent official statistical release of the Test of English as a Foreign Language (TOEFL iBT, 2017) in which the overall average score was 64 out of 120 for Saudis who took the TOEFL iBT from January to December 2016. This average score is the third lowest worldwide, and it is the lowest among all North African and Middle Eastern test takers. Therefore, with the current shortcomings with English learning in the Saudi context, it is crucial to introduce innovative ways to learn English with the use of technology to overcome the constraints that limit their gains. It is also important to investigate how learners interact and adopt innovation with their English learning, how the affordances enable their actions, and how their environment is reshaped by their actions.

\subsection{Statement of the Problem}

Although there are previous studies on the effects of technology utilization in the language classroom, many of these studies tend to focus on the outcome and attitudes associated with the use and adoption of technology with language learning, while less studies have explored the dynamics and complexity of the language learner's agency with the use of technology and the technology implementation process over time. In addition, there are less studies that explore the advantages of the use of WhatsApp outside the classroom for language learning. Although the introduction of the Internet, specifically the introduction of Web 1 and 2 applications, generated increased attention to employ the online environment to assist language teachers and learners in the Saudi context (e.g., Alothman, Robertson, \& Michaelson, 2017; Hamdan, 2014; Hammond \& Gamlo, 2015), it is important to investigate the learners' interaction with technology, in terms of exploring the affordances that enable their activities, and to investigate the constraints that might negatively influence their actions toward English learning; that is, to not only investigate the technological features but also the factors that might emerge from their language learning context (i.e., environment, tradition, and culture). The extent and nature of these challenges has been given little attention in the course of language learning in the Saudi context.

\subsection{Research Questions}

The aim of the study is to explore the students' use trajectory and experiences with WhatsApp outside the classroom and explore how the app's use could achieve sustainability for their English learning. The study was conducted in Saudi Arabia at Qassim University's Preparatory Year Program (PYP). The project seeks to research and answer the following questions:

1- How are the students' use trajectory and experiences with WhatsApp in their English learning experiences outside the classroom?

2- How sustainable is WhatsApp in assisting the students with their English learning? 


\section{Literature Review}

\subsection{Definitions of Agency}

The meaning of agency in language learning is still undergoing debate in applied linguistics. There are several definitions of agency that are mainly viewed through a sociocultural lens. One of the earliest and more specific definitions of agency comes from Layder (1997), who defined it as "the ability to take action in the light of a conscious assessment of the circumstances" (p. 35), while Ahearn expands the definition by providing a wider "provisional definition" stating that agency is "the socioculturally mediated capacity to act" (Ahearn, 2001, p. 112). Ahearn's definition allowed many researchers to expand and include other elements of agency in order to provide a varied conceptualization. For example, from Lantolf and Thorne's (2006) point of view, agency involves "voluntary control over behavior," which means that agency involves decisions to act; however, they also mention that it "entails the ability to assign relevance and significance to things and events" (p. 142-143). Furthermore, Lantolf and Thorne add that agency is "socioculturally mediated and dialectically enacted. In other words, within a given time and space, there are constraints and affordances that make certain actions probable, others possible, and yet others impossible" (p. 238). In other words, their explanation of agency is that it is not only a decision to act, but it also involves a behavior that is limited or enabled by the constraints or affordances in the settings that form the action of an individual. Similarly, agency is defined by Duff (2012) as "people's ability to make choices, take control, self-regulate, and thereby pursue their goals as individuals leading, potentially, to personal or social transformation” (p. 417, cited in White, 2018, p. 199). Duff's definition states that agency is enabled by individual goals. Duff also mentions that agency "actively resists certain behaviours, practices, or positionings" (Duff, 2012, p. 417, cited in White, 2018, p.199). Finally, Picard (2010) provides a slightly different definition from Lantolf and Thorne, arguing that agency is "an immutable characteristic of individuals that allows humans to act and to speak" (p. 4). The difference is that Lantolf and Thorne view agency as also visible during mutable action as long as the individual is conscious and has control over her or his own behavior. Therefore, even if the individual does not show a sign of interaction or speaking with another, it is still an act of agency, that is, a constrained agency by contextual factors.

\subsection{Van Lier's Agency Theory from an Ecological Perspective}

Van Lier's (2004) conceptualization of agency was adopted as the analytical framework for this study. Van Lier viewed agency from an ecological angle in which context is important to understand the dynamic reciprocal relation of the varied personal and environmental factors influencing the language learner as he "acts and interacts within and with his environment" (van Lier, 2004, p. 246). In other words, agency does not completely depend on the student, but it develops from the student's interaction with the environment's structural and contextual affordances. According to Kalaja, Barcelos, Aro, and Ruohotie-Lyhty (2015), a crucial element of the ecological approach is that the classroom environment "should be made favorable to the emergence and development of agency, as it is seen to be crucially influenced by the environment” (p. 16). Thus, there is a relational effect in viewing agency 
from an ecological approach in which the learner's agency is enabled by the awareness and use of the affordances, or limited due to the constraints, found in the environment.

Van Lier (2008) further developed the concept of agency is his paper "Agency in the classroom" in a way that assists in locating agency in the language classroom. In his article he argued about the difficulty in making a distinction between agency and other common concepts such as self-regulation, autonomy, self-initiation, and extrinsic and intrinsic motivation. However, by identifying agency with this familiar territory (autonomy, motivation, self-initiation, and self-regulation), van Lier (2008) managed to propose three main factors for locating agency which are also in line with the definitions of others (Ahearn, 2001; Lantolf \& Thome, 2006; Wertsch, Tulviste, \& Hagstrom, 1993). These factors include:

1) Agency involves initiative or self-regulation by the learner (or group).

2) Agency is interdependent, that is, it mediates and is mediated by the sociocultural context.

3) Agency includes an awareness of the responsibility for one’s own actions vis-à-vis the environment, including affected others (van Lier, 2008, p. 172).

As mentioned, van Lier's ecological approach to his agency theory is adopted as the analytical framework for this study as it aids in capturing agency during the learners' interactions with WhatsApp, and the constraints and affordances that emerge during their interaction within their environments. The agency theory is used to enable us to gain insight into the complexity and dynamic of the learner "whose language use, meaning making, and actions are mediated by their social and cultural world" (Deters, Gao, Miller, \& Vitanova, 2015a, p. 5). Thus, agency, in this study, is perceived as the dynamic, socioculturally mediated capacity to act where learners co-negotiate and co-construct their own learning ways through the use of WhatsApp (Ahearn, 2001; Lantolf \& Pavlenko, 2001; Lantolf \& Thorne, 2006; van Lier, 2004, 2008). This study recognize agency as action potentials that are limited or enabled by the learners' interaction with the constraints and affordances which are mediated by "social, interactional, cultural, institutional and other contextual factors" (van Lier, 2008, p. 171), and that agency encompasses awareness of the responsibility of one's actions in relation to the environment involving affected others.

\subsection{WhatsApp in Language Learning}

The potential of WhatsApp in assisting language learning was found to be significant in a number of empirical studies (Mufanti \& Susilo, 2016; Susilo, 2014). Susilo (2014), for example, applied WhatsApp and Facebook with 10 students in an English class at the Open University of Indonesia to explore the social networks' potential to enhance the students' collaboration and activity. Data gathering included interviews and content analysis, and by adopting a virtual ethnographic approach, the findings revealed that the use of WhatsApp and Facebook increased the students' activity. Furthermore, the study indicated that WhatsApp could have the potential to raise the learners' collaboration and activity outside their classroom, possibly due to the affordances that allow learners to easily share information anywhere and anytime. 
Several studies show the positive potential of WhatsApp to enhance language learners' activity achievements, confidence, motivation, and autonomy (e.g., Awada, 2016; biniti Mistar \& Embi, 2016; Mellati \& Khademi, 2015; Mufanti \& Susilo, 2016; Şahan, Çoban, \& Razi, 2016; Yavuz, 2016). For instance, a study published by Mufanti and Susilo (2016) found that WhatsApp could bring several advantages to the language classroom including the potential to enhance the learners' activity, motivation, confidence, and autonomy. Likewise, Gutierrez-Colon Plana et al. (2016) investigated the students' perception of the utilization of WhatsApp and found that the students' attitudes were positive toward the use WhatsApp with regard to their confidence as well as achievements in in their reading skills.

More specifically in the Saudi context, studies show that the use of WhatsApp has a positive impact on the students' English learning in terms of achievements, motivation, activity, and confidence. For instance, in a study conducted by Almekhlafy and Alzubi (2016) implemented WhatsApp in a language classroom with 40 Saudi EFL students in Najran University in order to use it as a tool to enhance students communication by allowing them to communicate with native English speakers on free-ranging activities and topics. The authors employed mixed methods for data collection which included semi-structured interviews with 10 participants and a questionnaire with 15 items. The findings reveal that the attitudes of the majority of the students were positive toward WhatsApp's use, and it assisted them with their English learning. Furthermore, the students also revealed that the utilization of WhatsApp raised their confidence and motivation, but reduced their anxiety, when speaking English.

Another study in the Saudi context is by Abdul Fattah (2015) who employed WhatsApp to enhance the achievements of Saudi EFL learners at the tertiary level. The results indicate a significant role played by WhatsApp to improve the learners' vocabulary, writing, and punctuation. The results also showed that the learners who used WhatsApp for their English learning outperformed the learners in the traditional classroom, especially in sentence punctuation and structure. These results are also in line with Alsaleem's (2013) findings in that there were great improvements in word choice and voice with the use of WhatsApp for the Saudi EFL tertiary learners.

Although these previous studies show that there is great potential for effectively utilizing WhatsApp in promoting the Saudis' language learning, however, studies exploring the complexity and dynamics of language learners' agency over time through the innovation's use, specifically the use of WhatsApp and social networking technology in general for English learning, is still lacking. Thus, more studies are needed to explore the potential of WhatsApp in promoting the language-learner's agency; that is, how the affordances or constraints that emerged from the dynamic and complex interactions of learners in their language learning environment and with the use of WhatsApp help them to pursue their learning aims. Moreover, the majority of the aforementioned studies tend to focus on quantitative elements of the research inquiry; although important, qualitative research methods could enhance the results of the quantitative studies, due to their ability to provide a deep investigation of the research inquiry through the learners' own voices. These concerns and gaps are explored in the current study. 


\section{Methodology}

The current study adopts a mixed method approach for data collection and analysis. The mixed method approach has many advantages, but what's more valuable is its ability to allow the triangulation of multiple data collection instruments which strengthens the validity and reliability of the data. The study involved 25 students from the Preparatory Year Program (PYP) at the Deanship of Educational Service (DES) of Qassim University. The DES's main responsibility is to manage and run the PYP (Al-Yahya, Mahmood, \& Lele, 2012). The PYP was found suitable mainly for two its two advantages: First, the emphasis of PYP is on English learning, and the teachers are non-Arabic speakers which requires students to communicate with them in English, since the teacher could only speak English. Second, the students of PYP have high GPAs as the entry requirements of PYP require high grades and usually the students are highly motivated due to the entry competition. The PYP is separated into four levels throughout a one-year period, and two semesters with two levels for each semester. Students attend classes for eight weeks in the first level, and then after taking the mid-term exam, they automatically progress to level two even if they have low grades. As this progression was programmed for the whole class, the classroom would continue as before with the same students. The first and second levels were considered appropriate for this study because the students at these levels could carry at least basic interaction in English, and they also need the most support to improve their English proficiency. Therefore, using WhatsApp might allow them to improve and accelerate their English proficiency.

For these levels, the students attend a total of 16 hours of English classes per week. The English classes are focused primarily on the four macro-skills of the English language, including reading, listening, speaking, and writing. To be more precise, the 16 hours are distributed into two subjects: Speaking and Listening for eight hours a week by one teacher and Reading and Writing for the remaining eight hours by another teacher. The WhatsApp project was implemented in Reading and Writing since it was the most appropriate. In addition, the use of WhatsApp did not conflict with the Reading and Writing's textbook since it was used outside the classroom. The textbook for the subject is Unlock Level 4 Reading and Writing Skills Student's Book and Online Workbook (published by Macmillan in 2014). Furthermore, all the other classes (such as computer, mathematics, etc.) were taught in English. The participants were all male students between 17 and 20 years of age and came from different cities in Qassim State, and a minority came from other states in the Kingdom of Saudi Arabia.

\subsection{Data Collection Instruments}

As previously mentioned, the present study adopted a mixed method approach to explore the use trajectory and experiences of WhatsApp outside the class for the students' EFL learning. Prior to the study I sought the participants' informed consent, I provided them with the information sheet, and I explained the study to them, including their rights to withdraw from the study at any time. The data was acquired from multiple data collection instruments, specifically six instruments, including: initial, post, and focus group semi-structured interviews; post-project questionnaire; observation; and research log. The initial interviews 
were conducted with 10 PYP students in the second week of WhatsApp's implementation. The same students attended the post-project interview in week 11 by the end of the study. In week 12, the same students as well attended the focus group interviews which were divided into two groups of five students each and lasted for about one hour per interview. The semi-structured interviews were used to enable the students to contribute in directing the interviews, and also to allow me to gain more information about other matters of interest which occurred during the interviews, and my observations of their utilization of WhatsApp (Dörnyei, 2007). The data was collected in 2015 in the second semester from 25 of Jan to 25 of April 2015.

Moreover, by the end of the study, specifically in week 12, all 25 students were asked to complete a post-project questionnaire which consisted of 16 items. The post-project questionnaire was aimed at investigating the students' perceptions, reflections, and evaluations related to the utilization of WhatsApp for their English language learning. The questionnaire was conducted online via surveymonkey.com, an online tool that aids in providing a basic analysis of quantitative data. The quantitative data was further uploaded to SPSS for a deep analysis. The questionnaire consisted of a five-point Likert scale ranging from strongly agree (1) to strongly disagree (5) and five open-ended items to enable the participants to demonstrate their feelings and opinions about their experience with WhatsApp. The researcher log and observations were conducted throughout the implementation phase.

The research gaps were used as a basis to structure the interviews and questionnaire. To avoid redundancy and errors in spelling and translation of the questionnaire, and, also to enhance the validity and reliability of the interviews, the design was piloted before the actual data gathering. All of the interviews were audio recorded and then transcribed.

\subsection{Data Analysis}

Descriptive statistics were used to analyze the questionnaire data, which involved the process of summarizing and describing the data in percentages and averages to be presented in tables and diagrams (Trochim, 2002). There was a bar chart for each item with a standard deviation (SD) and mean. Each questionnaire item was compared with others and then compared to the findings of interviews and other qualitative data to find any significant relation between the variables. SurveyMonkey and SPSS were utilized in the whole process of quantitative analysis.

The qualitative findings applied thematic analysis, including the responses of the participants on the open-ended questions and the interview transcripts. The aim of thematic analysis is to identify any theme from the data that might emerge to aid in understanding the studied research inquiry (Daly, Kellehear, \& Gliksman, 1997). The investigation of the theme required "careful reading and re-reading of the data” (Rice \& Ezzy, 1999, p. 258). This process requires, as Corbin and Strauss (2015) noted:

... breaking the data down into manageable pieces, reflecting upon that data . . . To arrive at an understanding of what the data are stating, there was a lot of 
brainstorming going on with questions asked about the data, comparison made and a lot of reflective thought. (p. 238)

The process of analysis begun by iterative examination of the whole interview transcript (initial and post-project, and focus-group, as well as observation and research log of WhatsApp implementation). Each page of the students' interview transcript was read, expressions or key words were underlined, and repetitions of what had been said were noted. At the same time, I also compared the themes of the interviews with the data from my own observations. The model of learner's trajectory of sustained motivation from Beltman and Volet (2007) was borrowed and redesigned to fit and manage the qualitative data findings and to track the trajectory of the students' utilization of WhatsApp over time. Finally, the analysis of qualitative findings was compared and related with the post-project questionnaire analysis in respect to the theory adopted for the study, until no new themes emerged.

\section{Results and Discussion}

\subsection{Moveable Classroom Context}

WhatsApp's most beneficial affordance for the students was its capacity to make a classroom environment outside the traditional one by representing a virtual connection between student, teacher, and the classroom environment. It was also easy to access anytime from anywhere outside of class. In the post-project questionnaire, the students reported to have a higher level of fulfillment and satisfaction with all aspects of WhatsApp, which primarily could be seen from item 20 of the questionnaire, where almost everyone agreed that WhatsApp was advantageous for English learning with a S.D. of just .57 (see Figure 1).

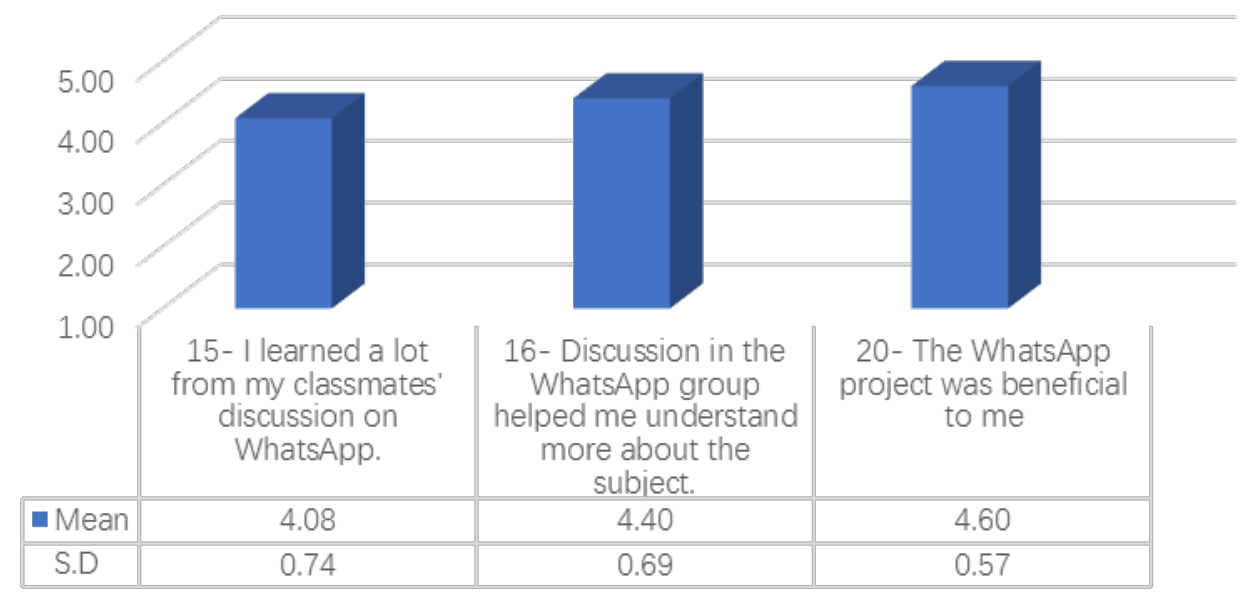

Figure 1. WhatsApp's post project questionnaire

Figure 1 shows that students perceived more benefit from their own inquiries (item 16) than from their classmates' (item 15), indicating the convenience of the students in initiating English practice virtually. The responses to item 15 might be triggered by some activities of their peers which were considered irrelevant, as some messages were shared solely for the 
purpose of entertainment. From the analysis for this part, it can be concluded that WhatsApp was considered by the students as an important platform, as it enabled them to initiate English practice independently without having to wait for the teacher to initiate English conversation.

\subsection{Immediacy and Ease of Use}

The immediacy affordance of WhatsApp showed that it might be linked to its ease of use. As shown in Figure 2, the responses to item 18, which was very high and agreed upon since the standard deviation is low as well, indicates that all responses detailed by the students were positive. Certainly, not only its ease of use, but also its immediacy made it easier to contact the teacher which helped to save their time and also removed the time constraint of the lecture.

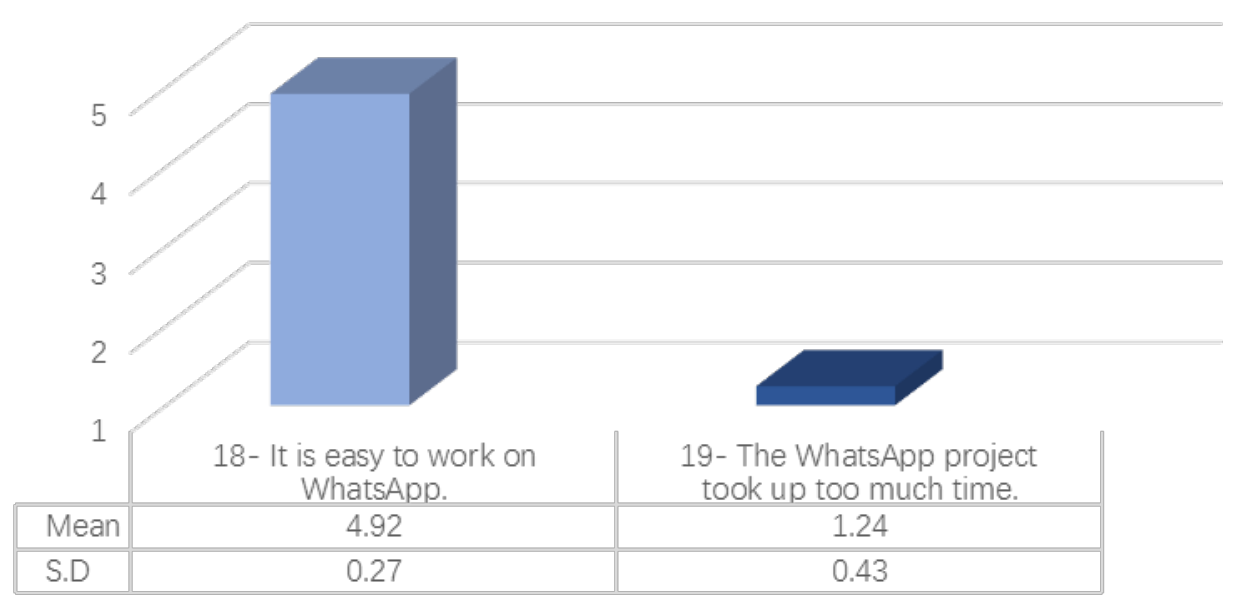

Figure 2. Ease of use and time consumption

The immediacy feature of WhatsApp was appraised in the interview as it enabled the students to actively learn English irrespective of place and time, as remarked in Ruaished's comment: "[I]t is available anywhere and there is no time limitation." The students might have been utilizing this feature as an affordance to increase their activity, particularly since WhatsApp could be accessed faster than any other social network, which helped them to easily access their teacher. Various studies in different contexts have confirmed the positive effects and significance of the ease of use of technology on the language learners' engagement (binti Mistar \& Embi, 2016; Joo \& Sang, 2013; Schoonenboom, 2014; Itayem, 2014). Furthermore, other theories such as UTAUT, DIT, TAM, and TAM2 argue that the main determinant of acceptance of technology by the users is its ease of use of a tool.

The invitation of the teacher to be a member of the group was also an essential element that played a crucial role in the enhancing of WhatsApp's immediacy. The interview revealed that as the teacher was also in the group, WhatsApp saved the student time. Ajlan, for instance, stated that WhatsApp afforded a mobile classroom environment for him as it enabled him to be in contact with his teacher whenever he needed: 


\section{Macrothink}

International Journal of Linguistics

ISSN 1948-5425

2018, Vol. 10, No. 6

If I need to ask my teacher a simple question, I don't have to meet him in the campus one week before the exam, I could just ask him via WhatsApp. (Ajlan)

By chatting with the students, the teacher built a kind of communal relationship and a sense of social presence that made him appear to be more available, both affectively and technically. As Fullan (2016) noted, the innovation's implementation need to engage the teachers in order to avoid its failure of sustainability. Thus, it can be concluded that the agency of the students with English learning was enabled and increased by two factors: WhatsApp's immediacy and the teacher's contribution.

\section{3 "All Students are Gathered on WhatsApp"}

The students' cooperation was strengthened due to WhatsApp's affordance that allowed them to be virtually connected to collaborate and answer their classmates' inquiries. As this feature meant the one who would answer questions was not limited to the teacher but also the peers, this allowed them to be more comfortable and more empowered to ask questions. The chance to receive a correct answer was also increased as they would receive not only one but various answers, as Oreny noted in the following comment:

If you ask one person a question, he might not know the answer. But because all of my classmates were grouping on WhatsApp, I might get 24 answers from one question I proposed, which can be considered as the advantage WhatsApp gives. (Oreny)

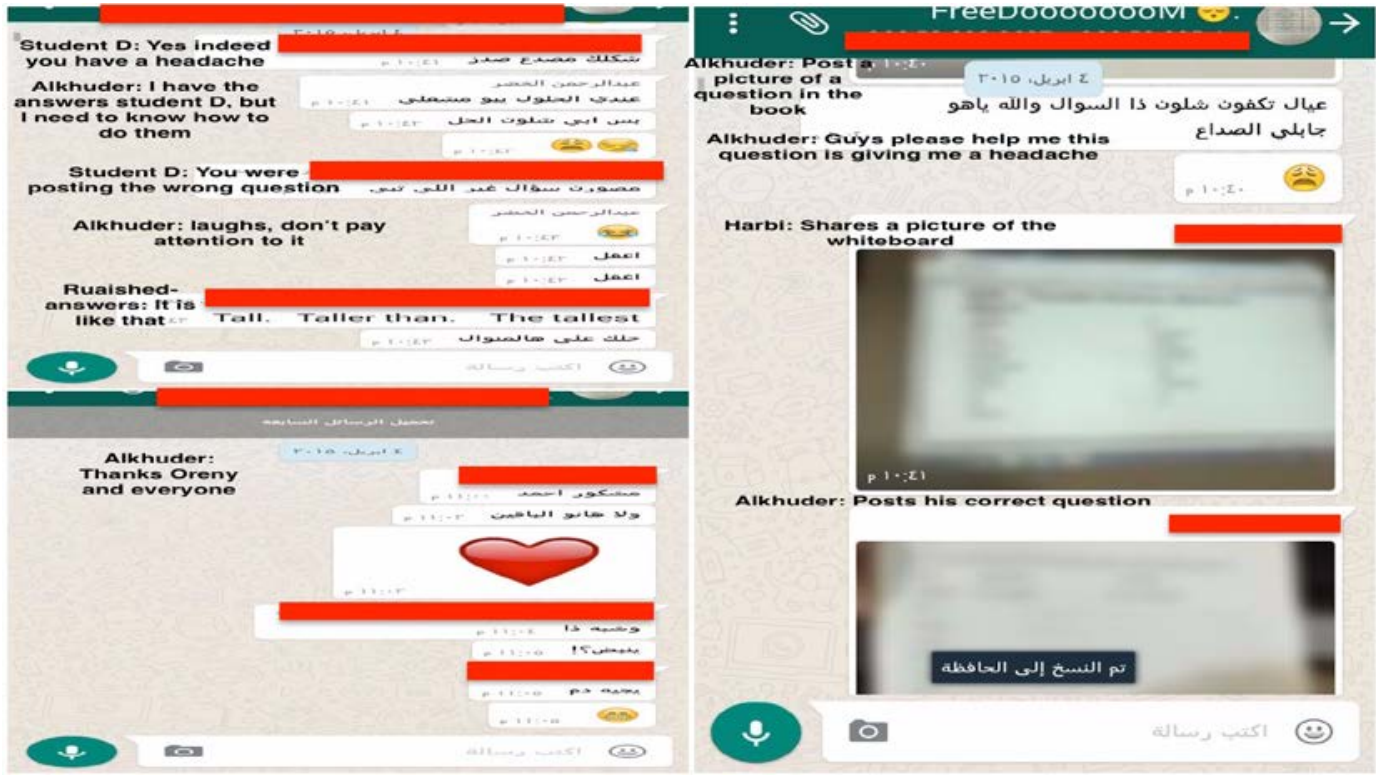

Figure 3. Cooperation between students

Oreny saw WhatsApp's ability to gather students and teacher in a group as an advantage which affords him to expand his engagement with English learning; that is, a student could receive multiple responses from posing one question. This decreased the dependency of the 
students on their teacher, as the students would still step in to provide an answer even if the teacher did not give a response immediately. Besides, these answers were still given under the supervision of the teacher (see Figure 3). The more the innovation was advantageous for the students, the greater the possibility of the innovation being adopted and actively used (Venkatesh \& Morris, 2003; Rogers, 2003). Consequently, the preferred standpoint was not only true for Oreny, but also for other students whose English learning could be positively influenced from answering the question.

Furthermore, Amry indicated that he gained performance benefits from the collaboration between the students on WhatsApp, not only because his questions were answered, but also because his English accomplishments were increased through multimedia sharing:

Amry:

Interviewer:

Amry:
WhatsApp is sometime used when we do group homework, revise the exams, solve the in-class unsolved problems, or share some pictures of reading paragraphs.

So, does this help you?

Yes, it helped improve my English proficiency and grades significantly.

As a virtual gathering space, WhatsApp provided an alternative information source for the students who did not attend class. This is because the other students usually share photos of the whiteboard or give explanations on what they had learned in class that day. This affordance by WhatsApp played an important role in enabling the students' agency to be cooperatively creating a virtual context where they could gather with their peers and teacher regardless of where they were at that moment. This finding is consistent with previous research, in which studies proved that WhatsApp could enhance the student's collaboration in language learning (Aburezeq \& Ishtaiwa, 2013; Rambe \& Chipunza, 2013). WhatsApp enabled the students to "define the meaning of their own acts within their social context" (van Lier, 2004, p. 8). Thus, WhatsApp opened up an environment in which the students could comfortably participate more often than face to face (FTF).

\subsection{Learning and Entertaining}

In relation to the aspect of WhatsApp's entertainment side, there were no comments about constraints that limited students' agency in the utilization of WhatsApp for English learning. Nonetheless, the entertaining messages which sometimes were sent by some students made some others feel uncomfortable. For instance, Alsumali disliked the irrelevant messages students sent, particularly during exams:

Alsumali: Yes, there were some futile conversations in the group prior to exams.

Interviewer: What do you think makes them send these types of messages prior to exams?

Alsumali: I think they get bored from studying and try to escape by interacting with 
the other students through jokes and pointless discussions.

It is true that, based on the observation of the students, the rate of entertainment messages increased during the period of exams. Early on, WhatsApp was found to be a good space for sharing humor, and under the pressure of exam period, this was exaggerated and exacerbated. However, this was not the case for everybody. As the humor was considered annoying by Alsumali, many other students considered these messages to be entertaining, enjoyable, and to even contain something to learn from. This could be seen from Abdullah's opinion:

The teacher often sends photos and useful materials which I could learn from on WhatsApp, particularly because I failed the last term and now I'm trying hard to enhance my grades and proficiency. Before, I only used WhatsApp for entertainment purpose but now I use it to learn and entertain. (Abdullah)

In this way, what was considered as beneficial by some, could be considered otherwise by others. Nonetheless, the entertainment-related activities did not actually limit or have a negative effect on the English learning activities of the students who may have been bothered by those messages. In fact, Alsumali was among the five students who were most active on WhatsApp. Besides, the entertainment-related activities could encourage students to be more active in their English learning. As van Lier (2004) noted, "for language learning to occur we need access to the information in the environment. This information cannot just be transmitted to us, we must pick it up while being engaged in meaningful activities” (p. 97). Thus, the first step to increase the engagement of students in language learning is to make them actively acquire "information from the environment while doing something, in order to do something else” (van Lier, 2004, p. 98). This could be observed from the intense activity in the WhatsApp group, with the traffic increasing to 1000 messages during exam days; their activities were usually lower during normal days when they could generate up to 500 messages. However, it is important to note that English learning related messages consisted of $20 \%$ to $30 \%$ of the total messages. Thus, it seems that a potential advantage of WhatsApp is the enabling of students' agency in English learning while making them active in entertainment.

\subsection{Multimodal Activity}

As I observed the process of WhatsApp's implementation, I noted that both the teacher and the students sent images on many useful subjects related to English language learning. For instance, when Alkhuder was asked about this, he expressed his appraisal of WhatsApp's feature to allow image sharing which, in his opinion, helped him improve his English proficiency. This was reflected in his comment:

WhatsApp is great and very useful as the students and teacher were sending English photos that you can read or translate. It was also useful to improve my grammar. (Alkhudar)

Interestingly, there were some whiteboard photos sent in the WhatsApp group by the students during the lecture. Amry explained this phenomenon as such: 
Interviewer:

Amry:

Interviewer:

Amry:

Interviewer:

Amry:
I found that you occasionally capture the board and send the picture to the group.

Yes, capturing it is faster than writing the content in the classroom.

Did you do that only for your friends who did not attend class that day?

No, not only for them, even they who were in the class not always able to write all the writings on the whiteboard.

So?

So we copy the writings from the picture of the board to our notebooks when we were at home.

As was shown in the discussion before, multimodal features of WhatsApp were increasingly utilized by the students as an affordance to expand their agency. Recent studies showed that taking pictures of writings on the board using smartphones was the current norm for the students (Klokmose \& Bertelsen, 2013; Varona-Marin, 2016). Hence, this phenomenon was not a new practice, and they might have done that long before using WhatsApp, to save time and to be able to focus more attention on what the teachers were saying. However, what is new in this action is that WhatsApp provides them with the ability to share these images with everyone in the class with less effort, which is also helpful for absent students. These two features of sharing and photo-taking give the students more opportunities to be active participants in learning English.

\subsection{Emotional Implications}

The students did not report any negative feelings that might influence them emotionally and thereby constrain their agency on WhatsApp in the interviews and the qualitative data. This is likely because WhatsApp increased their confidence more than FTF, as previously indicated in the post-project questionnaire response shown in Figure 4. Almost all students expressed a high level of confidence in the process of knowledge-sharing via WhatsApp. Only one student reported a neutral opinion. This is in line with previous studies that compared to face-to-face interactions; the employment of WhatsApp in learning was less likely to generate anxiety (Mufanto \& Susilo, 2016; Mistar \& Embi, 2016). 


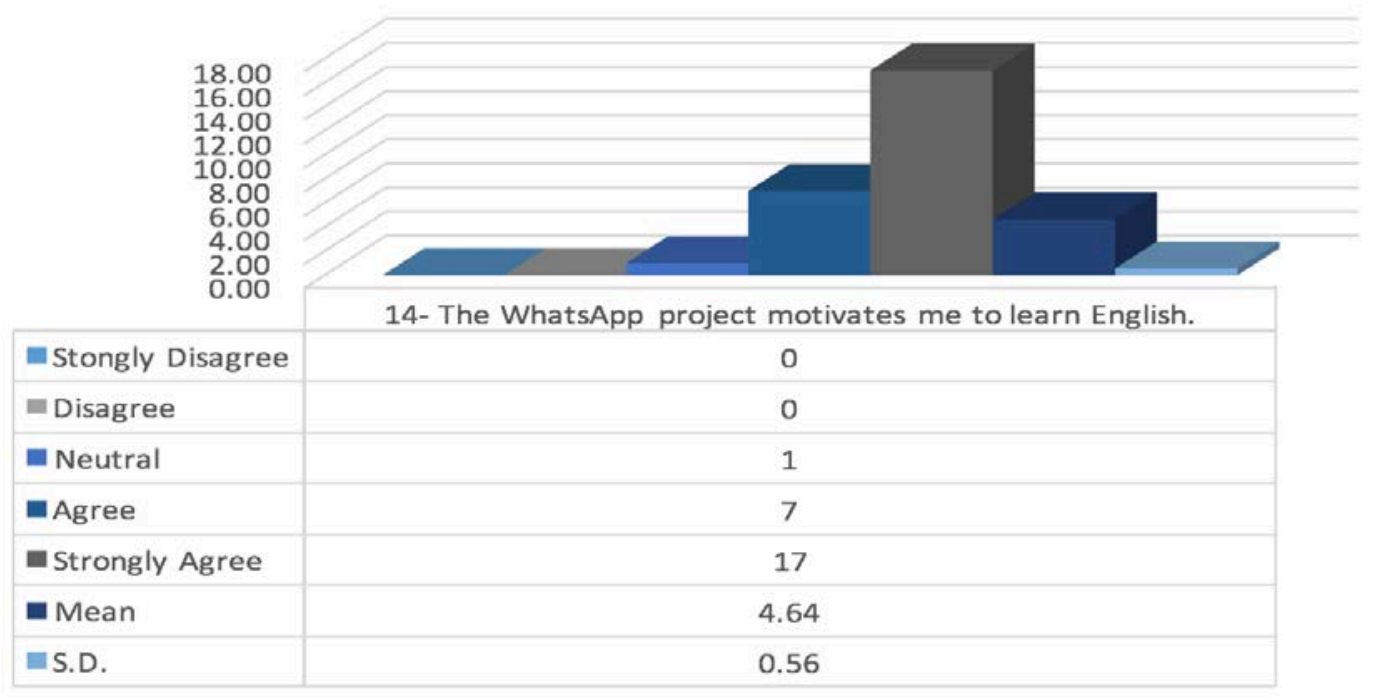

Figure 4. The students' confidence level on WhatsApp

Moreover, the increased level of student confidence in using WhatsApp seems to impact student activity positively. The students who were inclined to anxiety or shyness appeared to be less anxious when interacting on WhatsApp than in FTF, as explained by Alsumali. The high level of activity was related to students feeling that WhatsApp was a more convenient place to chat than the FTF situation with the teacher in class, especially since they actually wanted to partake in order to enhance their English skills:

I think it is because all of the students are willing to speak English, so each one of us is trying to find a sparring partner for it. Some of the students may not have friends to speak English with, or too pressured or confused when speaks English directly face to face, so they chat the teacher in the WhatsApp group, as writing is much easier. (Alsumali)

Alsumali's remark might show that the WhatsApp environment was different from FTF, i.e. the opportunities to practice English in FTF for Alsumali and his classmates were less due to contextual constraints existing in the FTF environment. This has been discussed in past studies which found the level of pressure and anxiety was lower for online text-based communication (e.g., Chan, 2011; Roed, 2003; Satar \& Özdener, 2008; Warschauer, 1996a). Besides, since students did not have to face their teacher and peers directly, the utilization of WhatsApp outside of class could increase convenience with the tool, as was found in previous studies (e.g., Aburezeq \& Ishtaiwa, 2013; binti Mistar \& Embi, 2016). Hence, WhatsApp seems to neutralize the anxiety constraint as Alsumali felt more confident practicing his English with his peers, and even his teacher, through WhatsApp.

\subsection{Private Chat}

Besides the group, the private chat feature of WhatsApp also acted as an affordance in facilitating the engagement of students during English language learning and further decreased their anxiety about making errors in front of their peers. This facility gave the 
students more privacy in proposing inquiries — even the ones that were considered 'easy' — so that they did not have to ask simple questions in the FTF setting, thereby overcoming its constraints. Oreny, for example, described this benefit with regard to asking simple questions:

Sometimes, there were some questions that I don’t want to ask in the group. So, during the exams period, when I was studying and didn't understand something, I would ask the teacher directly via private chat, and he would send me an explanation through the voice messages. Honestly, it was very advantageous. (Oreny)

Oreny was worried that he would be looked down upon by his peers if he asked a simple question, so he preferred to ask the teacher privately. Hence, a difficult question was proposed in the group, so it could be seen by all of the students, while the simpler ones were proposed via private messages. This phenomenon showed that WhatsApp's privacy increased the involvement of Oreny and other students in the process of English language learning by decreasing the anxiety and negative feelings which were related to the activity of asking simple question.

Before and during the period of the mid-term exam, the activity of the students on WhatsApp's private chat significantly increased. Numerous students stated that they often asked the teacher via the private message, particularly when studying for exams, and according to what was reported in the interview, the teacher was also very responsive. The privacy feature of WhatsApp in allowing the students to ask the teacher via private messaging was a perfect opportunity for Alkhuder to increase his English knowledge, as he was a shy student. In the interview, he revealed that he had a strategy to ask multiple questions without ruining his relationship with the teacher:

Interviewer: $\quad$ Did you ask him questions before the exams?

Alkhudar: $\quad$ Yes, I have. There are many things that I didn't understand before the exam like about half of the book, so I asked him one question a day on the remaining days before the exam.

Interviewer: $\quad$ Why didn't you ask all of the questions at once?

Alkhudar: $\quad$ I was afraid to bother him then he may refuse to answer my questions.

Nonetheless, he saved his questions for the following days to maintain a good relationship with the teacher, because he was worried that causing the teacher more work might affect his willingness to help him in the future. Hence, he was carefully exercising his agency to communicate via private messages with his teacher. The previous study by Susilo (2014) which examined the utilization of Facebook and WhatsApp in English learning class also found that WhatsApp was more actively used by the participants than Facebook, as WhatsApp's features were more private. 


\subsection{Community Relationship}

The affordances that positively influenced and played a significant role in the agency of students to engage with English language learning were not only the WhatsApp features, but also the closer community of the students, such as friends, family, and relatives. The students revealed that those who were closest to them were contributing in helping them to accept and be comfortable with the new tool as well as motivating them in learning in an indirect way. Figure 5 shows that most of the students strongly agreed that WhatsApp motivated them in English language learning, where the qualitative data related to this item indicated the presence of their closer community in the platform, the building of social relationships, and the competition of the peers, all of which increased the utilization and adoption of WhatsApp by the students. This is in accordance with what past studies have found: the closest community's influence positively affected their decisions to accept and use a technology (Polites \& Karahanna, 2012; Sicilia, Sáenz-Alvarez,\& González-Cutre, 2015).

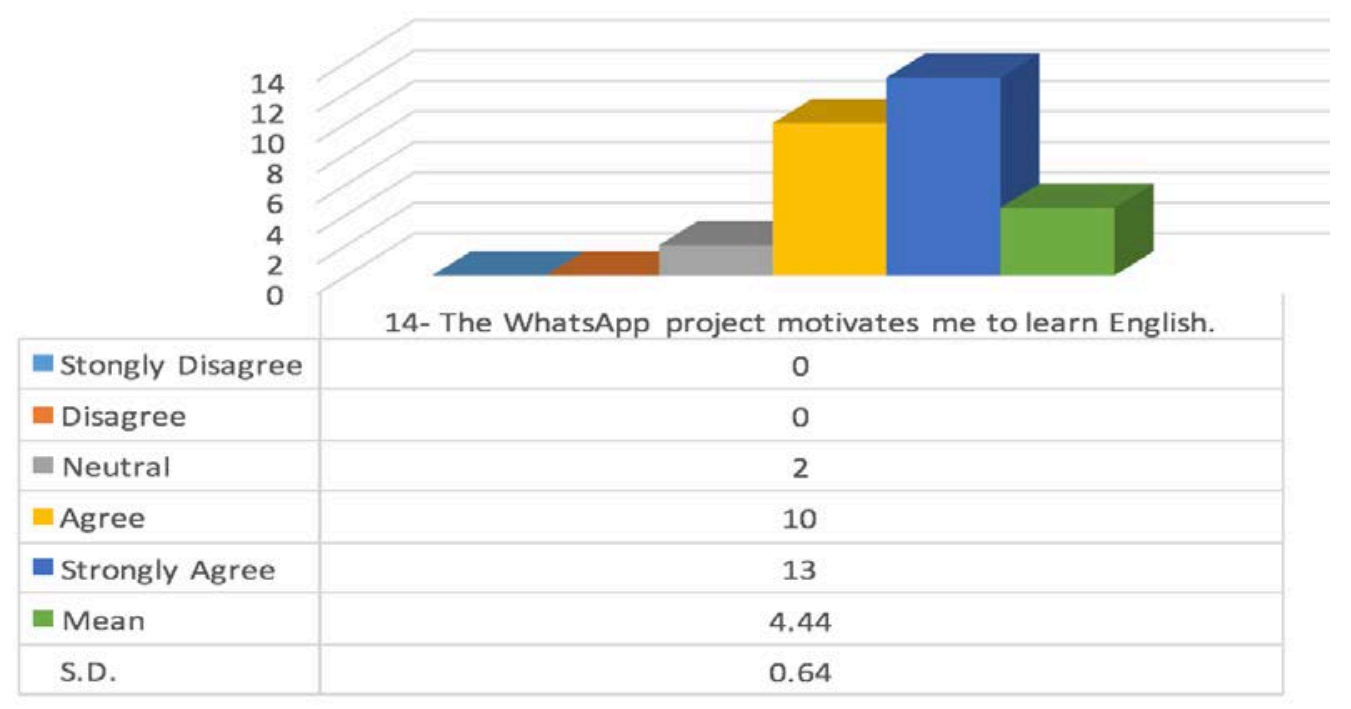

Figure 5. The students' motivation in WhatsApp

As shown by Ajlan's following comment, the students reported that the activities of their friends, families, and relatives on WhatsApp influenced their own activity on WhatsApp:

All of my family, friends, and relatives are active on WhatsApp, almost no one don't have an account there. It is also easy to use. (Ajlan)

According to Ajlan, his close community presence and activity played a significant role in helping him to accept the utilization of WhatsApp in his English language learning. This finding is parallel with the research by Rashidi, Vaniea, \& Camp (2016), who also found a positive correlation between the close community of the learner and the learner's technological utilization. I am currently working on another study where I applied Twitter to be used as a tool for English learning with the same participants in the classroom. However, the results show that the utilization of Twitter was not as sustainable as WhatsApp because the level of close community use was low and thus the employment of it would require extra 
effort. Thus, to enable the agency of the learners, it is crucial to give a social reason for the implementation of a new technology.

The other factor which also contributed in influencing the utilization of WhatsApp for the students' English language learning was their social relationship with their peers. These relationships were built as a way to develop motivation, which in turn influenced the students' agency. For instance, as reported by Oreny, he needed to keep up good relationships with his friends to remain active in his own studies, and WhatsApp was the tool used for this purpose. With the affordance of WhatsApp, his participation was not only about asking questions, but also answering the other students' inquiries, thus contributing in developing a sense of community:

I try to make many friends to keep myself motivated in class. I think you should not interact with the other students only when you need help. So at first I didn't know anyone so it was hard for me to participate, but as I already know all of them now, I am encouraged to participate more.

Oreny's purpose was not only to build social relationships with his classmates but also to serve the function of self-presentation as he wanted to be perceived as a diligent student. According to van Lier (2004), the utilization of technology and the Internet is a great way to "create a sense of community and to share linguistic information, create dictionaries, collect stories and myths, in general, to have [students'] voices heard” (p. 174). Along these lines, Oreny felt motivated and satisfied about his English ability when his peers asked him questions, as this was an indication that the other students trusted him. Thus, answering these questions acted as a catalyst for his agency. In the following comment, Oreny explains his experience of maintaining good relationships with his classmates:

When I succeed in answering my peers' questions, I imagine my other friends would say: "Oreny understands this well, we should also ask him the matters we don't understand," so all of them started to give me inquiries. For instance, just yesterday some students asked me questions in English via WhatsApp. (Oreny)

The main factor which motivated Oreny to build a relationship with the other students was recognition. As he imagined, if he kept answering those questions, his peers would think that "Oreny understands this well, we should also ask him the matters we don't understand." So, the questions proposed to him became motivation for him to maintain the image of a diligent student, one he wanted to present in front of his peers. WhatsApp afforded and facilitated this purpose, particularly because all the class members were grouped in one virtual place and available any time outside class hours, thus increasing the chance of answering those questions. Fullan (2007) argued that an innovation would be failed to be implemented in the context of education when it did not draw adequate attention from the general community. The connection with their students' closest community was the primary reason for them to start using WhatsApp for their English learning, and they eventually became actively involved in the virtual classroom. 


\subsection{Formal to Informal Relationships}

One of the advantages that was afforded by WhatsApp's use was the classroom environment's change from formal to informal, which then supported the process of English language learning (Al-Shehri, 2012). In the Saudi educational setting, the typical relationship between teacher and students is formal (Kojima, 2012), which consequently makes some students experience difficulty in gaining more support and help from the teacher for their English learning (Al-Shehri, 2012). This was the result of anxiety that the students felt when initiating inquiries in such a formal setting, as Alrabai (2014) noted. "The strict and formal learning environment in Saudi Arabia is a fundamental factor in learner anxiety” (p. 91). Tanveer's (2007) study also indicated the extremely stressful language learning situation students experience as a consequence of the formality of the Saudi EFL program. However, as the success of WhatsApp has emerged, this environment has started to change, and students participate more in WhatsApp-mediated English language learning than they did in FTF. The students submitted many inquiries to the teacher and took every opportunity to speak English with him. Likewise, the teacher also participated well in the group, and posted both English-related materials and entertainment messages. These actions by both the students and the teacher lower the tension between them, creating higher levels of comfortability on WhatsApp rather than with FTF learning. This was illustrated by Ruaished in the focus group interview:

I feel like speaking with my own friends when interacting with the teacher and the students via WhatsApp. (Ruaished)

Indeed, for the purpose of motivating and encouraging the students to learn, the teacher interacted informally with them, as if they were friends, when answering their questions. The teacher had a crucial role in influencing the students' agency as he developed the students' sense of belonging and made them feel comfortable to interact on WhatsApp. This was illustrated by Harbi as such:

The teacher is very friendly and motivating us in the group; he is willingly answering even the simplest questions from us. (Harbi)

When Ajlan was asked about how his WhatsApp experience was, he stated that the informal relationship has made him feel closer to his teacher, and the several conversations they had in the group caused him to be recognized by the teacher as an active and diligent student:

I feel closer to the teacher now in a casual way, as I asked the teacher questions for several times and this made him remember my name.

This could also be seen from the teacher's perspective-as the teacher became more informally connected to his students via WhatsApp, he was then involved on a deeper level in the students' interactions. By answering their questions, he encouraged them to enhance their English proficiency and thus positively influenced their agency. Bader noted that the teacher usually gave detailed explanations as a response to the students' questions, which can be seen in the following comment: 
He was great. He was willing to give detailed explanations when we ask him questions during the period of exams. (Bader)

This shows that the positive attitude of the teacher toward the innovative use of WhatsApp as a learning tool played a significant role in their activity. He was not only willing to be involved in the public group but also willing to engage personally with the students and help them in their struggles to learn English, whether by answering their inquiries or by finding a way to enhance their English skills. The teacher was responsible in fulfilling his duty to improve the students' English proficiency. In some cases, the teacher answered the questions during the office hours, particularly the ones which were sent privately. Ruaished, for example, noted the way his questions were answered: "He [the teacher] replied the message I sent two days prior on the day before the exam at around 12 to 1 PM.” Thus, the teacher could choose a suitable time to answer the students' questions if he sometimes felt burdened by them. The agency of the teacher broke down the constraints of cultural barriers which were preventing the students from actively exercising their agency before, such as hesitation in having an informal conversation with an elder (Algarfi, 2010), fear of losing face, and negative evaluation (Al-Khairy, 2013; Al-Saraj, 2013; Alqahtani, 2011; Alrabai, 2014; Hamouda, 2012). The students' learning environment was reshaped greatly by the actions of the teacher on WhatsApp, by providing them with an opportunity to comfortably practice their English. Both the students and the teacher agreed that WhatsApp created a new environment for them which strengthened and made their relationship more casual, thereby elevating their learning to another level.

Moreover, the capacity of the teacher to casually participate on WhatsApp enhanced the students' agency in learning English, or, specifically, in practicing the English language. According to my observation, the students were demonstrating more initiative in English language practice via WhatsApp rather than in the FTF setting. Abdullah, who also was aware of this phenomenon, argued that there was a rapid change in the students' attitude toward speaking English since the WhatsApp group was created. He stated that before, his peers had never spoken English with that much intensity:

Interviewer: How do you see your peers in the group?

Abdullah: $\quad$ They have changed a lot.

Interviewer: $\quad$ How?

Abdullah: $\quad$ Now they started to speak English really well as never before.

Interviewer: What caused this in your opinion?

Abdullah: $\quad$ Well since the teacher joined us in the group and he started to interact with us more than before when we were only interacting FTF in classroom. 


\section{Mll Macrothink}

International Journal of Linguistics

ISSN 1948-5425

2018, Vol. 10, No. 6

In conclusion, utilizing WhatsApp provided the students with the means they needed for learning English comfortably, which allowed them to interact informally with their peers and teacher. This finding is in line with the findings of other studies (e.g., Arnold, Ducate, \& Kost, 2009; Kessler, 2009; Kessler \& Bikowski, 2010), which also reveal that informal interactions supported by social networking increase the quality of language learning. In this research, the students' environments were modified by the informal relationship through the building of relationships which helped them to be closer to one another. Hence, it provided more opportunities for the students to express themselves and to feel more comfortable when interacting with their peers and teacher.

\subsection{Restructuring the WhatsApp Environment}

As the students gained success in utilizing WhatsApp for English language learning, they wanted to continue their success by interacting with their classmates via WhatsApp in other subjects like physics and computer science. The quantitative findings of the research, which can be observed in Figure 6, show a high rate of positive student attitudes toward the change in their WhatsApp environment with regard to the other subjects. All the students, as the table indicates, showed interest in the idea of using WhatsApp for other subjects, which they have already done intensively, as I have observed and the students' responses in the interviews show. For instance, Alsumali's remark painted a picture of how he had been influenced by his peers to cooperate via WhatsApp in the study of physics:

As some students started to share physics problems and inquiries on WhatsApp, I was also motivated to study physics via WhatsApp. (Alsumali)

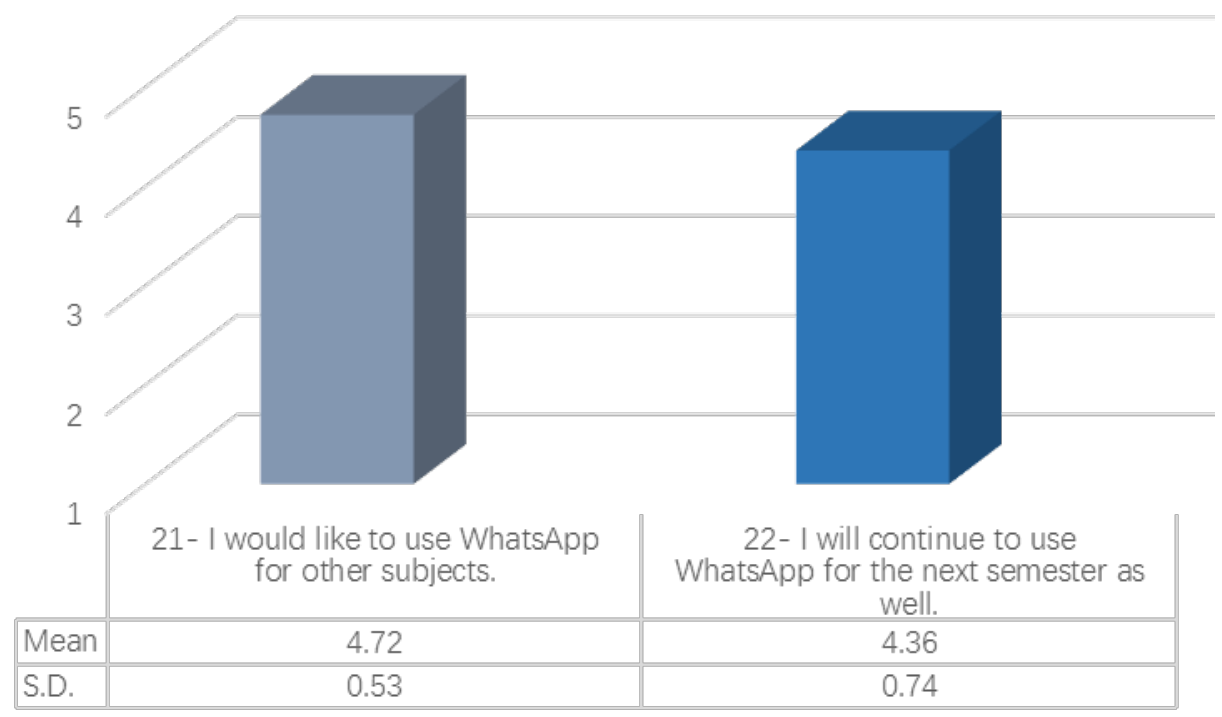

Figure 6. Students' attitude toward environmental change

I asked another student, Ajlan, who already used WhatsApp for his physics class, if he wanted his physics teacher to join the group; his answer was positive as he believed that the availability of the teacher would increase the quality of his physics studies: 


\section{Macrothink}

International Journal of Linguistics

ISSN 1948-5425

2018, Vol. 10, No. 6

I actually hope so, particularly for physics. If the physics teacher joined us in the WhatsApp group, it would help us to solve most of the problems. (Ajlan)

The agency of the students in the restructured environment via WhatsApp also meant that it had become an alternative mediator for learning various subjects other than English. This can be observed from the very high level of responses to item 22 (see Figure 6), which shows that the majority of the students agreed that they would like to utilize WhatsApp for the next semester. WhatsApp finally became embedded in the study habits of the students, as stated by Mubarak, who considered WhatsApp an essential part for his learning process:

WhatsApp obviously became a fundamental part of our learning, and once the next term starts, we will create a WhatsApp group and this is agreed by all the students. (Mubarak)

The sustainability of WhatsApp was proven by the students' positive behavior toward its usefulness in the long-term. According to Fullan (2007), for an innovation to be successfully sustained, the participants need to sustain its use within a specific period of time. This research shows that WhatsApp was utilized sustainably both by the teacher and the students until the end of the semester. (Interestingly, this study was planned to be conducted until week 12, but I had to finish the study and leave for New Zealand. Although I notified the participants, both in the WhatsApp group and in the classroom, they continued to use it with their teacher until the end of the semester.) By the end of the semester, the participants changed the group name to "FreedooooM," which indicates the students intense pressure during their first semester of PYP. After that, the students thanked everyone, including the teacher, and left one by one, as shown in the Figure 7.

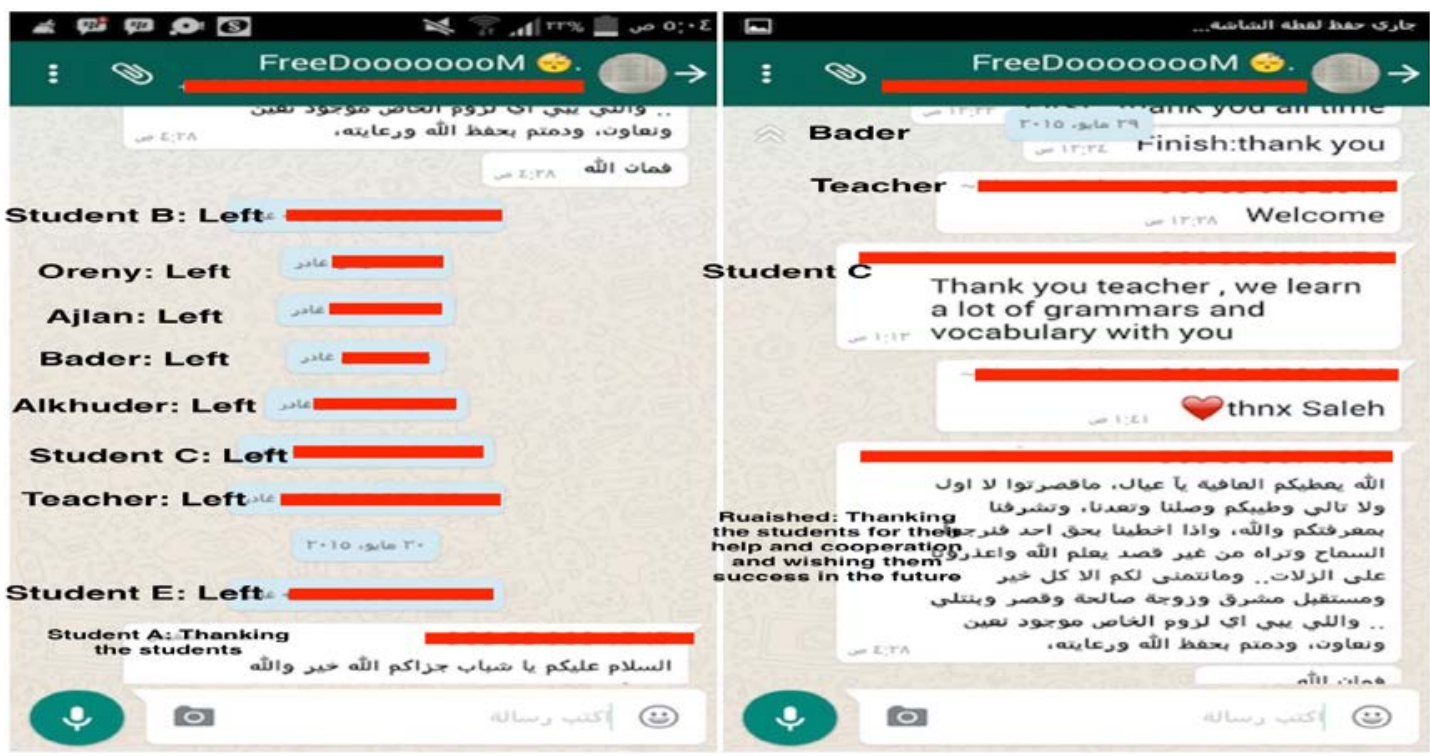

Figure 7. Students and teacher leaving the WhatsApp group on 29th of May 2015

According to Holmes, Clement, and Albright (2013), the sustainability of the innovation places primary attention on the actions taken by the individuals to make sure the advantage of the innovation will be available for a long period of time. The first action made was to utilize 


\section{Macrothink}

International Journal of Linguistics

ISSN 1948-5425

2018, Vol. 10, No. 6

WhatsApp until the end of the semester for English language learning. The second action was the use of WhatsApp to collaborate for other subjects such as computer science and chemistry, but especially physics as it was difficult for the students to approach the teacher. This shows that the students were able to develop autonomy which is also in line with previous study which reported that social networks foster learner autonomy (e.g., Alm, 2009; Zorous, Potalia, \& Zorois, 2017). Moreover, as Waters (2009) noted, successful and innovative projects must be made available for the use of multiple subjects for a wider and more sustainable impact. In conclusion, the use of WhatsApp allowed the students to develop independence in their learning, and more specifically in English language learning, as well as it successfully achieved sustainability.

\subsection{The WhatsApp use Trajectory}

The students' appraisal of the affordances and constraints of WhatsApp was observed during the use trajectory of WhatsApp for over 17 weeks (see Figure 8). Observations, a research log, first and post-project individual and focus group interviews, and the post-project questionnaire responses were used to appraise the students' use of WhatsApp over time by using the trajectory model of sustained motivation by Beltman and Volet (2007). The first row of the model consists of the aspects that occurred from WhatsApp's implementation, which can be seen as an affordance or a constraint. The second row of the model demonstrates the positive or negative views of the students toward these aspects. The last row demonstrates the advantages or disadvantages the students gained with regard to their English language learning. 


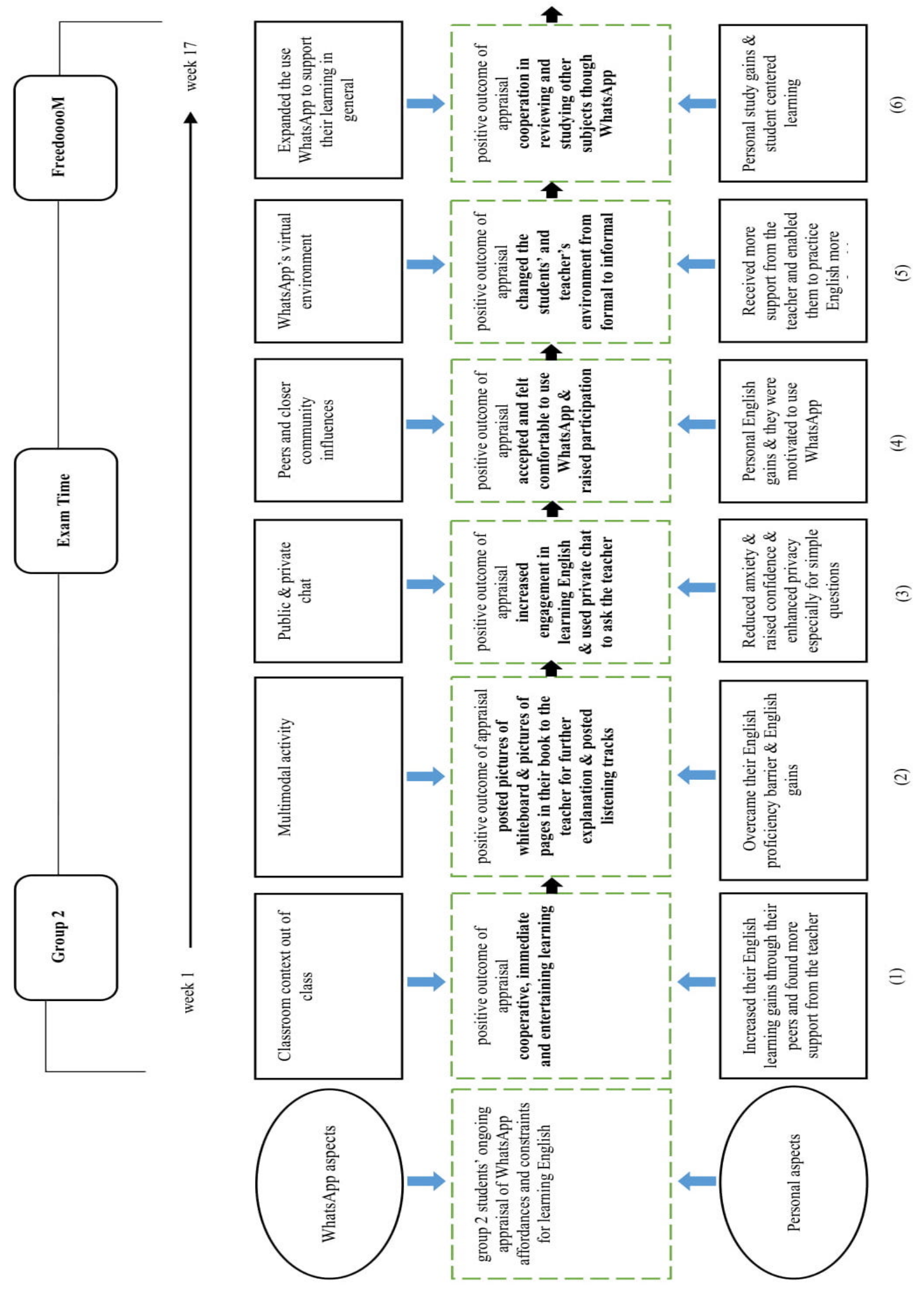

Figure 8. The WhatsApp innovation trajectory 


\section{Conclusion}

Given the current shortcomings of studies on social networking in general and more specifically for WhatsApp's innovation for language learning and approaching agency from van Lier's ecological perspective, I conducted this research in the Saudi social and cultural context of English learning. Agency theory allowed me to explore the actions of language learners, provide insights about the dynamics and complexity of those language learners' experiences and use trajectory of WhatsApp as an innovative language learning tool. The use of the agency theory as the analytical framework opened a door to a more profound comprehension of the role of constraint and affordance in the process of the decision-making of the learners in acting and adopting an innovative tool in the language learning context of a Saudi classroom. The theoretical implications of the current study placed an emphasis on the agency of the learners in the utilization trajectory of WhatsApp over time.

This study found that the main reason for the dynamics of the students' agency throughout the employment of WhatsApp was due to the ongoing interaction between the students and the learning contexts' constraints and affordances. As van Lier (2004) noted, the emergence of affordance in learning contexts has the potential to generate further actions. Although, many studies sought to investigate the students' behavioral intentions and the product in their utilization of an innovation, less studies have focused on the process of the innovation's implementation and the role of the innovation's affordances on the students' agency over a period of time in their sociocultural contexts. The moment-by-moment longitudinal study on the utilization of WhatsApp demonstrated that the adoption of a technology by students in the setting of language-learning was a dynamic process, complex, directed and extended by the occurrence of affordances in the environment that enabled or, through contextual constraints, prevented actions. Along these lines, this study's theoretical contribution expanded the scope of examination of a language-learning innovation. Rather than focusing on the overall impact of the innovation, this study focused more on the process of its acceptances and utilization over time within the sociocultural context of the learner, specifically focusing on the affordance of the technology that enabled learners' agency or the constraints of it that prevented the adoption of the technology.

This study confirms the view that the implementation of social networking technology, specifically WhatsApp, in the EFL classroom can offer a collaborative and convenient environment for students to practice and enhance the language they study. The utilization of WhatsApp in a Saudi EFL classroom has been shown to have some pedagogical potential, including the benefit of the affordances of the innovation in overcoming the contextual constraints, especially effective in increasing the students' and teacher's social interaction, altering the teacher's role, and developing the autonomy of the students. The use of social networking and WhatsApp has promising pedagogical implication and could potentially aid the Saudi Ministry of Education in achieving their goal of increasing the use of innovation in learning, and for Saudi English learning in particular. 


\subsection{Limitations and Further Research}

While this research has proven its value theoretically and pedagogically, it still has some limitations with regard to the participants' sampling, selection, gender in the longitudinal study, and the absence of the teacher interview, which impacted the generalizability of the study's results on different settings.

The first limitation concerns the participant selection in the longitudinal study, which was not chosen randomly. This selection process was reliant on the teacher who agreed to take part in the research and who was already assigned to a group of students before this study was implemented; therefore, his students automatically became my participants. Because the Saudi education system separates students by gender, female participants were consequently excluded from the longitudinal study due to access difficulties. Another limitation of the study is related to the time constraint which prevented me from interviewing the teacher about his experiences and perception of WhatsApp as a tool for English language learning, which, if done successfully, would strengthen the research findings. Even though part of the teacher's attitude toward the utilization of WhatsApp has been partially explained through the observations of his behavior and the students' interview responses, a direct interview with the teacher would surely enhance the analysis.

However, this study could be used as a basis for future research to explore the potential of the language learners' agency with the use of technology from an ecological viewpoint. To increase the generalizability of this study, though, such research has to eliminate the inadequacies of this present study. For instance, future research could also include female students as participants in a longitudinal study, conduct a study in a mixed-gender environment, or conduct the study on a sample larger than the current one, or explore the participants' interactions over a longer time period. Furthermore, I recommend an investigation of the teachers' agency and their perceptions of the utilization of WhatsApp inside and outside of the language classroom.

\section{References}

Abdul Fattah, S. F. E. S. (2015). The effectiveness of using WhatsApp messenger as one of mobile learning techniques to develop students' writing skills. Journal of Education and Practice, 6(32), 115-127.

Aburezeq, I. M., \& Ishtaiwa, F. F. (2013). The impact of WhatsApp on interaction in an Arabic language teaching course. International Journal of Arts \& Sciences, 6(3), 165-180.

Ahearn, L. M. (2001). Language and agency. Annual Review of Anthropology, 30, 109-137.

Al-Ahaydib, M. E. A. (1986). Teaching English as a foreign language in the intermediate and secondary schools of Saudi Arabia: Diagnostic study. Lawrence, KS: University of Kansas.

Albugami, S., \& Ahmed, V. (2015). Towards successful implementation of ICT in Saudi schools (literature review). Paper presented at the 12th International postgraduate research conference, Salford, Greater Manchester, UK. 


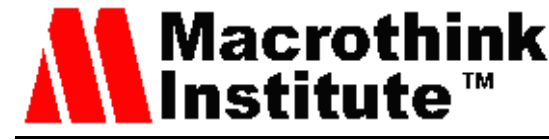

International Journal of Linguistics

ISSN 1948-5425

2018, Vol. 10, No. 6

Aldosari, H. (1992). A sociolinguistic of the attitudes of Muslims students, teachers and religious officials on learning and teaching English as a foreign language in Saudi Arabia. (Unpublished doctoral dissertation), Pennsylvania State University, PA.

Algarfi, A. (2010). Teachers' and pupils' perceptions of and responses to cooperative learning methods within the Islamic culture courses in one secondary school in Saudi Arabia. (Doctoral dissertation, University of Southampton, Southampton, UK).

Alhawsawi, S. (2013). Investigating student experiences of learning English as a foreign language in a preparatory programme in a Saudi university. (Doctoral dissertation, University of Sussex, Sussex, UK). Retrieved from http://sro.sussex.ac.uk/48752/1/Alhawsawi\%2C_Sajjadllah.pdf

Al-Johani, H. M. (2009). Finding a way forward: The impact of teachers' strategies, beliefs and knowledge on teaching English as a foreign language in Saudi Arabia. (Doctoral dissertation, University of Strathclyde, Glasgow, Scotland, UK). Retrieved from http://ethos.bl.uk/ProcessOrderDetailsDirect.do

Al-Khairy, M. H. (2013). English as a foreign language learning demotivational factors as perceived by Saudi undergraduates. European Scientific Journal, 9(32), 365-382.

Alm, A. (2009). Blogging for self-determination with L2 learner journals. In M. Thomas (Ed.), Handbook of Research on Web 2.0 and Second Language Learning. Hershey, NY: IGI Global.

Almekhlafy, S. S. A., \& Alzubi, A. A. F. (2016). Mobile-mediated communication a tool for language exposure in EFL informal learning settings. Arab World English Journal (AWEJ), $7(1), 388-407$.

Alothman, M., Robertson, J., \& Michaelson, G. (2017). Computer usage and attitudes among Saudi Arabian undergraduate students. Computers \& Education, 110, 127-142. https://doi.org/10.1016/j.compedu.2017.02.010

Alqahtani, M. (2011). An investigation into the language needs of Saudi students studying in British postgraduate programmes and the cultural differences impacting on them. (Doctoral dissertation, University of Southampton, Southampton, UK). Retrieved from https://eprints.soton.ac.uk/198175/1/Binder1.pdf

Alrabai, F. (2014). A model of foreign language anxiety in the Saudi EFL context. English Language Teaching, 7(7), 82-101. https://doi.org/10.5539/elt.v7n7p82

Alrabai, F. (2016). Factors underlying low achievement of Saudi EFL learners. International Journal of English Linguistics, 6(3), 21-37.

Alresheed, S., Leask, M., \& Raiker, A. (2015). Integrating Computer-Assisted Language Learning in Saudi schools: A change model. The Turkish Online Journal of Educational Technology, 14(4), 69-77. 


\section{Al Macrothink}

International Journal of Linguistics

ISSN 1948-5425

2018, Vol. 10, No. 6

Alsaleem, B. I. A. (2013). The effect of" WhatsApp" electronic dialogue journaling on improving writing vocabulary word choice and voice of EFL undergraduate Saudi students. Arab World English Journal, 4(3), 213-225.

Al-Saraj, T. M. (2013). Foreign language anxiety in female Arabs learning English: Case studies. Innovation in Language Learning and Teaching, 8(3), 257-278. https://doi.org/10.1080/17501229.2013.837911

Al-Seghayer, K. (2014). The four most common constraints affecting English teaching in Saudi Arabia. International Journal of English Linguistics, 4(5), 17-26.

Al-Shehri, S. (2012). Contextual language learning: The educational potential of mobile technologies and social media. (Unpublished doctoral dissertation), University of Queensland, Brisbane, Australia.

Al-Yahya, S. A., Mahmood, A., \& Lele, U. (2012). QU Bulletin 2012 - Humanitarian and Community. Retrieved from http://www.qu.edu.sa/en/quDocuments/QUManual/QU Bulletin 2012 - Humanitarian and Community.pdf

Arnold, N., Ducate, L., \& Kost, C. (2009). Collaborative writing in wikis: Insights from culture projects in intermediate German classes. In L. Lomicka \& G. Lord (Eds.), The next Generation: Social networking and online collaboration in foreign language learning (pp. 115-144).

Asiri, R. M. M. (2014). The religious objectives of English curriculum in Saudi Arabia. King Khalid University, 1-19.

Awada, G. (2016). Effect of WhatsApp on critique writing proficiency and perceptions toward learning. Cogent Education, 3(1), 1-25. https://doi.org/10.1080/2331186X.2016.1264173

Beltman, S., \& Volet, S. (2007). Exploring the complex and dynamic nature of sustained motivation. $\quad$ European psychologist, 314-323. https://doi.org/10.1027/1016-9040.12.4.314

binti Mistar, I., \& Embi, M. A. (2016). Students' perception on the use of WhatsApp as a learning tool in ESL classroom. Journal of Education and Social Sciences, 4(1).

Chan, M. (2011). Shyness, sociability, and the role of media synchronicity in the use of computer-mediated communication for interpersonal communication. Asian Journal of Social Psychology, 14(1), 84-90. https://doi.org/10.1111/j.1467-839X.2010.01335.x

Chun, D. (1994). Using computer networking to facilitate the acquisition of interactive competence. System, 22, 17-31. https://doi.org/10.1016/0346-251X(94)90037-X

Corbin, J., \& Strauss, A. (2015). Basics of qualitative research (4th ed.). Thousand Oaks, CA: SAGE Publications.

Daly, J., Kellehear, A., \& Gliksman, M. (1997). The public health researcher: A methodological approach. Melbourne, Australia: Oxford University Press. 


\section{Mll Macrothink}

International Journal of Linguistics

ISSN 1948-5425

2018, Vol. 10, No. 6

Deters, P., Gao, X., Miller, E. R., \& Vitanova, G. (2015). Introduction to theorizing and analyzing agency in second language learning: Interdisciplinary approaches. In P. Deters, X. Gao, E. R. Miller, \& G. Vitanova (Eds.), Theorizing and analyzing agency in second language learning: Interdisciplinary approaches (pp. 1-13). Bristol, UK: Multilingual Matters.

Dörnyei, Z. (2007). Research methods in applied linguistics: Quantitative, qualitative, and mixed methodologies. Oxford, UK: Oxford University Press.

Duff, P. (2012). Identity, agency, and second language acquisition. The Routledge handbook of second language acquisition, 14, 410-441.

Fullan, M. (2007). The new meaning of educational change (4th ed.). New York, NY: Teachers College Press.

Fullan, M. (2016). The new meaning of educational change (5th ed.). New York, NY: Teachers College Press.

Gutierrez-Colon Plana, M., Gimeno, A., Appel, C., \& Hopkins, J. (2016). Improving learners' reading skills through instant short messages: A sample study using WhatsApp. In A. Gimeno-Sanz, M. Levy, F. Blin, \& D. Barr (Eds.), WorldCALL: Sustainability and computer-assisted language learning. London, UK: Bloomsbury Publishing.

Hamdan, A. K. (2014). The reciprocal and correlative relationship between learning culture and online education: A case from Saudi Arabia. The International Review of Research in Open and Distributed Learning, 15(1), 310-336.

Hammond, M., \& Gamlo, N. H. (2015). How and why do language teachers use ICT in a University in Saudi Arabia? Global Conference on Learning and Technology "The Local Global Conference", (pp. 248-257). Berlin, Germany: Proceedings of Global Learn.

Hamouda, A. (2012). An exploration of causes of Saudi students' reluctance to participate in the English language classroom. International Journal of English Language Education, 1(1), 1-34.

Holmes, K., Clement, J., \& Albright, J. (2013). The complex task of leading educational change in schools. School Leadership \& Management, 33(3), 270-283. https://doi.org/10.1080/13632434.2013.800477

Itayem, G. (2014). Using the iPad in language learning: Perceptions of college students. (Doctoral dissertation, The University of Toledo, Toledo, OH). Retrieved from http://utdr.utoledo.edu/cgi/viewcontent.cgi?article=2714\&context=theses-dissertations

Joo, J., \& Sang, Y. (2013). Exploring Koreans’ smartphone usage: An integrated model of the technology acceptance model and uses and gratifications theory. Computers in Human Behavior, 29(6), 2512-2518. https://doi.org/10.1016/j.chb.2013.06.002 


\section{Mll Macrothink}

International Journal of Linguistics ISSN 1948-5425 2018, Vol. 10, No. 6

Kalaja, P., Barcelos, A. M. F., Aro, M., \& Ruohotie-Lyhty, M. (2015). Beliefs, agency and identity in foreign language learning and teaching. Basingstoke, Hampshire, UK: Palgrave Macmillan.

Kern, R. G. (1995). Restructuring classroom interaction with networked computers: Effects on quantity and characteristics of language production. The Modern language journal, 79(4), 457-476. https://doi.org/10.1111/j.1540-4781.1995.tb05445.x

Kessler, G. (2009). Student-initiated attention to form in wiki-based collaborative writing. Language Learning \& Technology, 13(1), 79-95.

Kessler, G., \& Bikowski, D. (2010). Developing collaborative autonomous learning abilities in computer mediated language learning: Attention to meaning among students in wiki space. Computer Assisted Language Learning, 23(1), 41-58. https://doi.org/10.1080/09588220903467335

Khan, I. (2011). Learning difficulties in English: Diagnosis and pedagogy in Saudi Arabia. Educational Research, 2(7), 1248-1257.

Klokmose, C., \& Bertelsen, O. (2013, September). The mysterious whiteboard. Paper presented at the 14th International Conference on Human-Computer Interaction (INTERACT), Cape Town, South Africa.

Lankshear, C., \& Knobel, M. (2006). New literacies: Everyday practices and classroom learning (2nd ed.). Maidenhead: Open University Press.

Lantolf, J. P., \& Pavlenko, A. (2001). (S)econd (L)anguage (A)ctivity theory: Understanding second language learners as people. In M. P. Breen (Ed.), Learner contributions to language learning: New directions in research (pp. 141-158). London, UK: Pearson Education.

Lantolf, J. P., \& Thorne, S. L. (2006). Sociocultural theory and the genesis of second language development. Oxford, UK: Oxford University Press.

Layder, D. (1997). Modern social theory: Key debates and new directions. London, UK: UCL Press.

Mellati, M., \& Khademi, M. (2015). The impacts of distance interactivity on learners' achievements in online mobile language learning: Social software and participatory learning. International Journal of Web-Based Learning and Teaching Technologies (IJWLTT), 10(3), 19-35. https://doi.org/10.4018/ijwltt.2015070102

Ministry of Communication and Information Technology. (2009). National Plan for Information Communication Technology. Riyadh, Kingdom of Saudi Arabia: MOCIT Press.

Mitchell, B., \& Alfuraih, A. (2017). English language teaching in the Kingdom of Saudi Arabia: Past, present and beyond. Mediterranean Journal of Social Sciences, 8(2), 317-325. https://doi.org/10.5901/mjss.2017.v8n2p317 
Mufanti, R., \& Susilo, A. (2016, September). Establishing a WhatsApp conversation: One of innovations in English language teaching. Paper presented at the Proceedings of the 63rd TEFLIN International Conference, Surabaya, Indonesia.

Picard, E. K. (2010). A radical relational agency: Foucault, complexity theory and environmental resistances. (Doctoral dissertation, University of Nottingham, Nottingham, UK). Retrieved from http://eprints.nottingham.ac.uk/11450/1/Thesis.pdf

Polites, G. L., \& Karahanna, E. (2012). Shackled to the status quo: The inhibiting effects of incumbent system habit, switching costs, and inertia on new system acceptance. MIS Quarterly, 36(1).

Rajab, H. (2013). Developing speaking and writing skills of L1 Arabic EFL learners through teaching of IPA phonetic codes. Theory and Practice in Language Studies, 3(4), 653-659. https://doi.org/10.4304/tpls.3.4.653-659

Rambe, P., \& Chipunza, C. (2013, August). Using mobile devices to leverage student access to collaboratively-generated resources: A case of WhatsApp instant messaging at a South African University. Paper presented at the International Conference on Advanced Information and Communication Technology for Education, Hainan, China.

Rashidi, Y., Vaniea, K., \& Camp, L. J. (2016, February). Understanding Saudis’ privacy concerns when using WhatsApp. Paper presented at the the Workshop on Usable Security San Diego, CA.

Rice, P. L., \& Ezzy, D. (1999). Qualitative research methods: A health focus. Melbourne, Australia: Oxford University Press.

Roed, J. (2003). Language learner behaviour in a virtual environment. Computer Assisted Language Learning, 16(2-3), 155-172. https://doi.org/10.1076/call.16.2.155.15880

Rogers, E. M. (2003). Diffusion of innovations (5th ed.). New York, NY: Free Press.

Şahan, Ö., Çoban, M., \& Razı, S. (2016). Students learn English idioms through WhatsApp: Extensive use of smartphones. Erzincan Üniversitesi Eğitim Fakültesi Dergisi Cilt-Sayi, 18(2), 1230-1251. https://doi.org/10.17556/jef.72045

Saqlain, N., Al-Qarni, F., \& Ghadi, N. (2013). Are English language teachers in Saudi Arabia ready to integrate technology? Procedia-Social and Behavioral Sciences, 103, 146-153. https://doi.org/10.1016/j.sbspro.2013.10.319

Satar, H., \& Özdener, N. (2008). The effects of synchronous CMC on speaking proficiency and anxiety: Text versus voice chat. The Modern language journal, 92(4), 595-613. https://doi.org/10.1111/j.1540-4781.2008.00789.x

Schoonenboom, J. (2014). Using an adapted, task-level technology acceptance model to explain why instructors in higher education intend to use some learning management system tools more than others. Computers \& Education, 71(1), 247-256. https://doi.org/10.1016/j.compedu.2013.09.016 


\section{Mll Macrothink}

International Journal of Linguistics

ISSN 1948-5425

2018, Vol. 10, No. 6

Sicilia, Á., Sáenz-Alvarez, P., González-Cutre, D., \& Ferriz, R. (2015). Analysing the Influence of Autonomous and Controlling Social Factors Within the Theory of Planned Behaviour. Australian Psychologist, 50(1), 70-79. https://doi.org/10.1111/ap.12077

Susilo, A. (2014). Exploring Facebook and WhatsApp as supporting social network applications for English learning in higher education. Applications for English Learning in Higher Education, 10-24.

Tanveer, M. (2007). Investigation of the factors that cause language anxiety for ESL/EFL learners in learning speaking skills and the influence it casts on communication in the target language. (Master's thesis, University of Glasgow, Scotland, UK). Retrieved from https://www.researchgate.net/publication/293263722_Investigation_of_the_factors_that_caus e_language_anxiety_for_ESLEFL_learners_in_learning_speaking_skills_and_the_influence_ it_casts_on_communication_in_the_target_language

TOEFL iBT. (2017). Test and score data summary for TOEFL iBT® tests. Retrieved 17 August, 2017, from https://www.ets.org/s/toefl/pdf/94227_unlweb.pdf

Trochim, M. K. (2002). What is the Research Methods Knowledge Base? Retrieved from http://www.anatomyfacts.com/research/researchmethodsknowledgebase.pdf

Van Lier, L. (2004). The ecology and semiotics of language learning: A sociocultural perspective. Boston, MA: Kluwer Academic Publishers.

Van Lier, L. (2008). Agency in the classroom. In J. P. Lantolf \& M. E. Poehner (Eds.), Sociocultural theory and the teaching of second languages (pp. 163-186). London, OH: Equinox Publishing Ltd.

van Lier, L. (2010). Forward: Agency, self and identity in language learning. In B. O'Rourke \& L. Carson (Eds.), Language learner autonomy: Policy, curriculum, classroom (pp. ix-xiv). Switzerland: International Academic Publishers.

Varona-Marin, D. (2016). The Lifecycle of a whiteboard photo: Post-meeting usage of whiteboard content captured with mobile devices. (Master's thesis, University of Waterloo, Ontario, Canada). Retrieved from https://uwspace.uwaterloo.ca/bitstream/handle/10012/10546/varonamarin_danniel.pdf?seque nce $=1$

Venkatesh, V., Morris, M. G., Davis, G. B., \& Davis, F. D. (2003). User acceptance of information technology: Toward a unified view. MIS quarterly, 27(3), 425-478. https://doi.org/10.2307/30036540

Warschauer, M. (1996a). Comparing face-to-face and electronic discussion in the second language classroom. CALICO journal, 13(2-3), 7-26.

Warschauer, M., \& Grimes, D. (2007). Audience, authorship, and artifact: The emergent semiotics of Web 2.0. Annual Review of Applied Linguistics, 27, 1-23. https://doi.org/10.1017/S0267190508070013 


\section{Macrothink}

International Journal of Linguistics

ISSN 1948-5425

2018, Vol. 10, No. 6

Waters, A. (2009). Managing innovation in English language education. Language Teaching, 42(4), 421-458. https://doi.org/10.1017/S026144480999005X

Wertsch, J. V., Tulviste, P., \& Hagstrom, F. (1993). A sociocultural approach to agency. In E. A. Forman, N. Minick, \& C. A. Stone (Eds.), Contexts for learning: Sociocultural dynamics in children's development (pp. 336-356). Oxford, UK: Oxford University Press.

White, C. (2018). Language teacher agency. In S. Mercer \& A. Kostoulas (Eds.), Psychology in Language Teaching (pp. 196-210): Multilingual Matters.

Yavuz, F. (2016). Do smartphones spur or deter learning: A WhatsApp case study. International Journal of Science Education, 15(3), 408-415.

\section{Copyrights}

Copyright for this article is retained by the author(s), with first publication rights granted to the journal.

This is an open-access article distributed under the terms and conditions of the Creative Commons Attribution license (http://creativecommons.org/licenses/by/4.0/) 